\title{
Civil Society Organizations at the Gates? A Gatekeeping Study of News Making Efforts by NGOs and Government Institutions
}

\begin{abstract}
This article applies a combination of an input-output content analysis and in-depth interviews with NGO communication professionals to determine whether the growing incorporation of press releases in editorial print content could be a new public forum through which international political actors, such as NGOs, could gain wider news access by serving as emerging key players in global civil society. The study indicates that Belgian news coverage of international aid issues is more often based on NGO press releases than government press releases. We also found that the agenda building capacities of NGOs and government institutions are enhanced as journalists present information subsidies as original journalistic work in most cases. Nonetheless, we must tone down prevailing one-sided conclusions, as most press releases are not just copy-pasted. Instead, most are supplemented with additional sources and information. The data, moreover, identify different journalistic roles of NGOs according to their objectives. While some issue press releases to raise short-term public awareness and donations for humanitarian crises (mobilization), others have developed into established expert news source organizations which provide background information and reliable eyewitness accounts to journalists.
\end{abstract}

\section{Keywords}

News access, NGOs, agenda building, global civil society, public sphere 


\section{Civil Society Organizations at the Gates? A Gatekeeping Study of News Making Efforts by NGOs and Government Institutions}

\section{Introduction}

The mass media are central in the conceptualization of a public sphere, which refers to an arena "which is dedicated to open-ended discussion and debate, the proceedings of which are open to entry and accessible to scrutiny by the citizenry" (Webster 2011:24). The widest possible representation of viewpoints in the news is a precondition for participants in the public sphere to make the best possible decision (Habermas 1974, 1992). "Put succinctly, who gets 'on' or 'in' the news is important" (Cottle 2000:427). Yet, research has shown that news access is strongly determined by the distribution of power and resources. Studies repeatedly demonstrated how established sources - especially politicians, government institutions and well-resourced companies - enjoy privileged news access compared to nonmainstream sources, including ordinary citizens and non-governmental organizations (NGOs) (Cottle 2000; Gans 1979, 2011; Hall et al. [1978] 1999; Sigal [1973] 1999; Wolfsfeld 2011).

In the contemporary news ecology that is characterized by the tendencies of cost-cutting, globalization and digitalization, the power relationships between these different types of actors fluctuate and their ramifications are far-reaching. On the one hand, some authors, including Davies (2008), describe how traditional media brands increasingly cut costs for purely economic reasons. As a result of contracting newsrooms, journalists are inclined to use press releases as "information subsidies" (Gandy 1982) to manage their workload. Several studies have demonstrated that public relations (PR) boost the already privileged news access of established third parties such as politicians or corporations, as they can afford to invest in media-tailored communication strategies (Curtin 1999; Lewis et al. 2006; McManus 2009). On the other hand, some scholars underline the need to move beyond this narrow view of PR as the "handmaiden" of political and corporate power, pointing to 
opportunities in source professionalization for more balanced news access for a wider range of actors (Greenberg, Knight and Westersund 2011:65). Central in this line of thought is the expansion of civil society to the global level which is an outcome of the growing gap between the global scene, where problems such as environmental pollution or terrorism arise, and the nation-state, where these problems must be managed (Cammaerts and Van Audenhove 2005; Castells 2008; Curran 2010). Accordingly, this article explores a constellation of news sources that journalists can draw upon in the global public sphere. International NGOs (INGOs) are taking part in global civil society as they deploy new digital leverage to offer their expertise and eyewitness accounts in media packages to journalists (Castells 2008; Powers 2012).

Few studies, however, have empirically examined whether INGOs' news management strategies result in more balanced news access. Therefore, this article empirically investigates to what extent the prevailing trends of cost-cutting, globalization and digitalization have changed the dynamics between journalists and their sources. In contrast to many studies of changing journalist-source relationships (e.g., Lewis et al. 2006), we do not approach this question from the perspective of the journalist, instead, we take on the perspective of the source. Focusing on Belgium as home base to the European Union and as a hub for INGO activity with many agencies headquartered in Brussels, we compare the news access for two so-called privileged or established news sources, the Belgian Ministry of Foreign Affairs and the European Commission, to two emerging sources of news, the INGOs Médécins sans Frontières (MSF) and the Belgian Consortium for Relief Help 12-12. For this purpose, the study applies a quantitative and qualitative input-output analysis to investigate how and to what extent press releases by these two different types of organizations are adopted in the foreign news coverage of four Belgian newspapers. The results are further informed by a series of in-depth interviews with communication professionals in the Belgian departments of INGOs. In the literature review, we first discuss the emerging role of NGOs as a news source. Subsequently, we elaborate on source strategies of agenda building within the contemporary news environment. 


\section{International NGOs: The new(s) kids on the block?}

Several authors point to the vital role of foreign reporting in a globalized world (Joye 2010; Sambrook 2010). However, numerous studies have demonstrated that international news coverage, including international aid coverage, is dominated by authoritative sources and especially government sources, who provide a national framework to interpret international news events (Lee et al. 2005; Livingston and Bennett 2003; Paterson 2006). The dominance of government sources in foreign reporting is exacerbated by cost-cutting strategies in newsrooms all over the world. The declining number of foreign correspondents and specialized reporters further increases the news media's dependence on international news agencies and information subsidies from official or other well-resourced sources (Sambrook 2010; Volkmer and Fridaus 2013). This growing presence of pre-packaged information in the news production process however offers possibilities to NGOs to influence the media agenda and gain increased prominence in news coverage, especially as we witness a shift from the public sphere situated within the nation-state to the global public sphere (Castells 2008, 2010; Cottle 2009; Volkmer 2003). The development and rapid rise of new digital networks provided the technological basis for the globalization of society, a "process that constitutes a social system with the capacity to work as a unit on a planetary scale in real or chosen time" (Castells 2008:81). In this new global playing field, traditional nation-states are confronted with global, non-state actors such as international corporations, that often undermine their power (Fenton 2010; Vargas and Paulin 2007). Castells (2008:83) points out that this "decreased ability of nationally based systems to manage the world's problems on a global scale has induced the rise of a global civil society". While public confidence in traditional politics is decreasing, the social and political role of NGOs is enhanced as they take part in this global civil society and react to the challenges and problems in the globalized world as advocates of citizens' needs, interests, values, and rights (Fenton 2010).

The field of NGOs or "formal, 'non-statutory', non-profit-making organizations" (Deacon 2003:99) is enormously broad and diverse. However, in the context of this article that 
discusses the development of a global public sphere, we focus on international NGOs (INGOs). We dwell on the definition of Castells (2008:84), who refers to INGOs as "private organizations (albeit often supported or partly financed by public institutions) that act outside government channels to address global problems. Often they affirm values that are universally recognized but politically manipulated in their own interests by political agencies, including governments. In other words, international NGOs claim to be the enforcers of unenforced human rights". Their activities focus on practical problems or specific cases that are internationally recognized (Benthall 1993; Castells 2008; Fenton 2010) such as the fight against lapidation of women ("issue management", Davies 2008:185). In contrast to Castells, nonetheless, we are aware of the fact that INGOs not always operate outside government channels. In many cases they are part of global governance for example as "experts" on UN panels, as lobbyists that exert pressure on international policy makers concerning certain topics, or as deliverers of welfare programs in the absence of functioning states. Well-known examples of INGOs are Greenpeace, Oxfam, Amnesty International, and MSF.

The primary strategy for NGOs to gain trust and support is through news coverage of their activities and achievements. Citizens are mobilized via media reports and news access is necessary to exert pressure on governments or multinationals (Blumler and Gurevitch 2005; Castells 2008; Davis 2000, Davies 2008; Fenton 2010; Gaber and Willson 2005; Thrall et al. 2008; Waisbord 2011). If we also take the changing media ecology into account, where news organizations increasingly save costs to the detriment of foreign coverage (cf. supra), it is obvious that journalists are increasingly compelled and less reluctant to rely on the expertise of INGOs as information providers on global issues and advocates of the public interest (Curtin 1999; Powers 2012; Reich 2011). To our knowledge, the extent to which this is happening has not been comprehensively empirically tested, however, a number of studies exist that provide evidence for this claim. For one, Fenton (2010) interviewed several NGO communication managers who stated that it has become easier for them to insert themselves into the news production process as foreign news desks are contracting. 
In this respect, public relations are a powerful tool for NGOs to acquire news access in a "more dynamic process of contestation in given fields of discourse" (Davis 2000:50). Additionally, the development of a global civil society has resulted in a dramatic rise in the number of (I)NGOs over the last several decades (Cottle 2009; Fenton 2010; Kennedy 2009). As a consequence, (I)NGOs today regularly face direct competition for news access, not only from established news sources such as government officials, but also from other (I)NGOs (Cottle and Nolan 2007; Fenton 2010). The combined result of these forces is that NGOs are professionalizing their public relations activities in order to become "news shapers" (Manheim 1998). Several studies have demonstrated the overall instrumentalization and marketization of the global aid and development field (Chouliaraki 2013; Cottle 2009; Deacon 1996; Miller 1993) as well as the incorporation of a "media logic" or, more specifically, a "journalistic logic" in NGOs' communication efforts to gain news access (Cottle and Nolan 2007; Fenton 2010; Greenberg, Knight and Westersund 2011; Waisbord 2011). With respect to media coverage, some NGOs have meticulously constructed an image of a reliable and credible news source organization ("authorized knowers", Fenton 2010:155) by means of sophisticated media strategies, including collaborations with scientists or politicians (Davis 2010; Livingston and Asmolov 2010; Waisbord 2011). Other NGOs produce their own research reports (Gaber and Willson 2005) or try to gain media attention by organizing "pseudo events" (Boorstin [1962] 1992), by installing celebrities as NGO ambassadors (Cottle and Nolan 2007; Fenton 2010; Gaber and Willson 2005; Thrall et al. 2008), or by providing "home connections" in disaster reporting by focusing on the work of national delegates (Cottle and Nolan 2007). Almost all NGOs have by now installed paid or voluntary communication officers "who are in charge of news management tasks, such as maintaining Web sites and social media, producing news releases and newsletters, holding press conferences, and reaching out to reporters" (Waisbord 2011:147). To enhance news access, NGOs regularly take up the role of news gatherer and news producer by delivering "media packages" or "information subsidies" to newsrooms (Aday and Livingston 2008; Davis 2010; Fenton 2010; Sambrook 2010; Vargas and Paulin 2007; Waisbord 2011). Nevertheless, 
there is little empirical proof with respect to whether and to what extent these PR activities can open the (news) gates for the new global players as compared to more established third parties. These questions are the focus of our empirical analysis, but we first discuss different aspects of agenda building.

\section{Source strategies: Levels of agenda building}

If successful in their attempt to "publish their information subsidies, practitioners influence the media agenda, the public agenda and public opinion, a process known as agenda building" (Sallot and Johnson 2006:152). However, in terms of their overall impact on the content of the news, we can distinguish between three distinct levels of agenda building.

The first level examines the circumstances that influence whether public relations can put a topic on the media agenda, thus telling us "what to think about" (Sallot and Johnson 2006:152). If the press release can open the gates, the second level concerns itself with the degree to which PR information is adopted by journalists in terms of "what to think" (Sallot and Johnson 2006:152). Journalists can copy and paste the press release verbatim, presenting it to the public as the "legitimate" way to think. Alternatively, they could also expand upon the PR material with contrasting points of view or critical background information that diminish the strength of the argument in the press release. Moreover, researchers often underestimate people's ability to critically process the news and form their own opinion (Castells 2010; Orgad and Vella 2012; Seu 2011). Most authors state that NGOs are rather unsuccessful in their PR efforts at both levels of agenda building. For example, Lewis et al. (2006) not only found that NGO press releases rarely resulted in coverage, they also observed that NGO PR material is mostly used in a fragmented way in that often no more than a quote extracted from the press release "to provide a contextual or opposing viewpoint to the main focus of a piece" (Lewis et al. 2006:23). Nonetheless, and as indicated above, Fenton (2010:161) concluded from interviews with NGO communication managers that "the majority of NGOs felt that because of the space that journalists are now 
required to fill and the time pressures in which they do it, their copy gets picked up more readily and more rarely gets changed".

Here, we point to a third level of agenda building, which is related to the fact whether journalists admit the use of PR material in the news or instead - as a defense mechanism to maintain their professional image of active "news breakers" that pursue the public interest prefer to veil their (often routine) interactions with source professionals. These consist not only of press releases but also include personal relationships and other more subtle contacts between the two parties. As PR professionals want to present their information subsidies as original journalistic content that serves the public interest instead of a form of free advertising in favor of specific private interests, we can state that source efforts are more successful when information subsidies are presented as the result of independent journalistic news gathering and production (Davies 2008; Davis 2000; Van Hout and Jacobs 2008). Reich (2010:811), for instance, found that PR practitioners are identified as information sources in no more than $11 \%$ of the observed cases as their presence in the news is mostly covered in what he calls a "smokescreen of anonymity". Furthermore, many press releases indirectly end up in the hands of journalists as part of news agency copy which they unsuspiciously believe to be original journalistic content. This established "multi-staged process of news sourcing" or "ladder of news sourcing" is nonetheless a key complication for researchers who attempt to quantify the use of PR material in journalistic products (Franklin 2011:101). Therefore, we will discuss in the next section, we adopted a multimethod approach to studying the effectiveness of NGO and government source strategies in the Belgian press.

\section{Methodology 1}

This article examines the assumption that the incorporation of press releases in editorial content could be an avenue for INGOs to gain wider news access. The research design consists of a combination of a quantitative and qualitative content analysis of Belgian newspapers, supplemented by in-depth interviews with INGO communication professionals. 
Considering that PR material is often concealed in the news output (e.g., Reich 2010), we conducted an input-output content analysis (Lams 2011; Quandt 2008) of press releases and the corresponding foreign news output in four Belgian newspapers in 2011. In light of our conceptual framework that discussed the proliferation of INGOs that promote specific global issues (Castells 2008), our focus lies on press releases following international aid projects. We selected four actors representing the two different types of organizations that we have discerned in the literature review: two established government institutions and two INGOs (more specifically two international aid agencies) that combined with the news media compose the "crisis triangle" (Cottle and Nolan 2007). The focus on international aid coverage further links to the conception of our modern society as a world risk society (Beck 1992) that is increasingly preoccupied with invisible, unpredictable, and uncontrollable risks, including disasters, poverty, pandemics and conflicts.

At the input side, we selected the Belgian departments of two INGOs: Médecins Sans Frontières (MSF) and the Belgian Consortium for Relief Help (Consortium 12-12). Although MSF and Consortium 12-12 are both INGOs, their functioning as international aid agencies differs substantially. MSF has evolved from a small organization in lack of resources before the 1980s to the world's largest independent medical relief organization that throughout the year publicizes international crises and its own aid missions (Dechaine 2002 in Fenton 2010:155). "Importantly, to gain widespread acceptance by the mainstream media, MSF also had to project a 'public image of neutrality' not so far removed from the journalistic ethics of objectivity and neutrality" (Fenton 2010:156).

By contrast, Consortium $12-12$ is a temporary cooperation between five aid organizations that is only activated at times of major international crises such as most recently the Syrian civil war. Interestingly, it was established in the late 1970 s as a technique of fundraising in response to a request from the news media to speak with one voice and to provide one account number in times of major emergencies (Philippe Henon, interview; Mooijman 2005). In many respects the Consortium is very similar to Britain's Disaster Emergency Committee 
in terms of "an influence for cooperation and coordination, to balance the growing competitiveness" (Benthall 1993:54). By including these two INGOs we can investigate a broader scale of PR efforts and compare their effectiveness. As Consortium 12-12's main purpose is to achieve intensive, short-term media exposure for fundraising, we expect that Consortium 12-12's press releases will be featured more often in the news output than MSF press releases. In addition to the NGOs, we have selected the Belgian Ministry of Foreign Affairs and the European Commission as two established source organizations that compete with INGOs for news access. All press releases of these two institutions are available on their website where we have filtered out all press releases about international aid to compare them with the INGO press releases.

At the output side, our sample consists of two popular ( $\underline{\text { Het Nieuwsblad } \text { and Het Laatste }}$ Nieuws) and two up-market (De Standaard and De Morgen) newspapers. These are Belgium's four most important newspapers in the Dutch-speaking region (De Bens and Raeymaeckers 2010). We collected all international aid press releases of the four organizations in 2011 and searched for the corresponding foreign news output in the four newspapers. In first instance, we gathered all news articles that contained the name of the organization as a keyword in the online Belgian newspaper database Mediargus. From this original selection that includes all news articles about the four target organizations in the sample period (including those not inspired by PR material), we only analyzed all articles appearing up to seven days subsequent to the dissemination of the press releases that bore a clear resemblance to the original PR material. This resemblance could involve a verbatim reproduction of (parts of) the press release, but even if no sentences are literally copypasted, it can still be clear from the overall content or particular point of view that the journalist has used information from the press release. In total, 196 press releases and 56 newspaper articles were selected for the quantitative analysis (Wester, Renckstorf and Scheepers 2006) following the research design of Buijs et al. (2009) and Lewis et al. (2006) with a focus on the degree of verbatim reproduction at the level of a sentence as a measure 
of reproduction. However, due to the different focus (domestic versus foreign news) and scope of our research (conventional content analysis versus input-output analysis), international comparisons must be made with caution.

The quantitative findings are further elaborated and illustrated first by means of a more indepth qualitative content analysis (Wester, Renckstorf and Scheepers 2006) of the selected press releases and news articles. The coding was conducted by two independent researchers (a trained student from the master program in journalism studies and the first author of this article) who relied on a coding sheet for the quantitative analysis, and who made transcripts of the qualitative analysis (e.g., which other sources are used in the article, and what are they saying). Their interpretations of the research material were then one-onone compared to ensure the consistency and reliability of the research findings. Secondly, the analysis was expounded by means of interviews with five communication professionals who work for the analyzed INGOs to deepen our understanding of their PR efforts (see Table 1). These interviews were conducted in June/July 2009 as part of a stand-alone research project but given their focus on INGO media relations in a Belgian context they are particularly relevant in light of the conducted content analyses. The interview respondents all work as communication professionals for MSF or one of the five aid organizations that take part in the Belgian Consortium for Relief Help (Caritas, Oxfam, Unicef). The interviews with Erik Todts (Oxfam) and Philippe Henon (Unicef) are especially relevant, as they are also the official chairman and, press and communication officer for Consortium 12-12. As a result, they were able to offer insights on the functioning and media planning of the Consortium.

Table 1. Overview of interviews with NGO communication professionals in June/July 2009

\begin{tabular}{|l|l|c|c|}
\hline Interview & Name & Affiliation 1 & Affiliation 2 \\
\hline 1 & Gerda Wylin & Caritas International Belgium & Consortium 12-12 \\
\hline 1 & Joëlle Verriest & Caritas International Belgium & Consortium 12-12 \\
\hline 2 & Koen Baetens & MSF Belgium & $/$ \\
\hline
\end{tabular}




\begin{tabular}{|l|l|c|c|}
\hline 3 & Erik Todts & Oxfam Solidarity Belgium & Consortium 12-12 \\
\hline 4 & Philippe Henon & Unicef Belgium & Consortium 12-12 \\
\hline
\end{tabular}

All analyses were conducted in view of the following two key research questions that emerged from the literature review. Our first research question deals with the degree to which INGOs gain news access by means of PR material compared to established sources (agenda building in terms of "what to think about"). We compared the uptake by Belgian newspapers of government press releases to the uptake of INGO press releases. Related to this is the question of whether Belgian newspapers integrate relatively more Consortium 1212 press releases than MSF press releases in their news output. Secondly, the analysis examined the extent to which press releases of the four selected organizations are simply reproduced in the news article, thereby succeeding in imposing a preferred interpretation framework, and to what extent the use of press releases is veiled in Belgian newspapers, thereby presenting them as independent journalistic products instead of pre-packaged news or free advertising (agenda building in terms of "what to think").

\section{Results}

In general, 196 press releases resulted in 56 news articles. As five news articles contained press release material by two different organizations, we have a total sample of 61 press releases $(31.1 \%)$ that were traceable in the news coverage. These numbers are too low for advanced statistical analyses. However, they do allow for descriptive analyses. When combined with the interviews, they point to some important differences between the four source organizations. This section is organized around the two main research questions. 


\section{RQ1: Differences in news uptake between the organizations}

Table 2 shows that Consortium 12-12 is most successful in gaining news access by means of information subsidies, as 16 of its 27 press releases $(59.3 \%)$ resulted in news coverage. MSF (37.3\%) and the Belgian Ministry of Foreign Affairs (32.4\%) complete the top three positions. The European Commission is lagging far behind, with a success rate of only $15.1 \%$, although it sent out most press releases. In absolute numbers, MSF takes the lead, followed by Consortium 12-12, the Belgian Ministry of Foreign Affairs, and the European Commission. These findings indicate that distributing more press releases does not automatically result in more news coverage. As many journalists complain of "press release overload", this does not seem to be the best strategy to set the news agenda. Our interviewees agree that "if you communicate too much, you undermine your own message because people will stop paying attention to it" (Philippe Henon, Unicef/Consortium 12-12).

Table 2. Overview of published press releases per newspaper $(\mathrm{N}=196)$

\begin{tabular}{|l|c|c|c|c|c|c|c|}
\hline & $\begin{array}{c}\text { De } \\
\text { Standaard }\end{array}$ & $\begin{array}{c}\text { De } \\
\text { Morgen }\end{array}$ & $\begin{array}{c}\text { Het } \\
\text { Laatste } \\
\text { Nieuws }\end{array}$ & $\begin{array}{c}\text { Het } \\
\text { Nieuwsblad }\end{array}$ & $\begin{array}{c}\text { Total } \\
\text { articles } \\
(1)\end{array}$ & $\begin{array}{c}\text { Total } \\
\text { press } \\
\text { releases } \\
(2)\end{array}$ & $\begin{array}{c}\text { Ratio } \mathbf{1} \text { (2 } \\
(\%)\end{array}$ \\
\hline MSF & 9 & 8 & 2 & 3 & 22 & 59 & $\mathbf{3 7 . 3}$ \\
\hline 1212 & 2 & 5 & 6 & 3 & 16 & 27 & 59.3 \\
\hline $\begin{array}{l}\text { Foreign } \\
\text { Affairs }\end{array}$ & 1 & 4 & 5 & 2 & 12 & 37 & $\mathbf{3 2 . 4}$ \\
\hline $\begin{array}{l}\text { European } \\
\text { Commission }\end{array}$ & 2 & 5 & 3 & 1 & 11 & 73 & $\mathbf{1 5 . 1}$ \\
\hline Total articles & 14 & 22 & 16 & 9 & 61 & 196 & $\mathbf{3 1 . 1}$ \\
\hline
\end{tabular}

The relatively higher success rate of INGO press releases compared to the two government institutions confirms that journalists are compelled to rely on INGOs as information providers on international aid issues (Davis 2010; Powers 2012). This assumption was confirmed in the interviews, where Erik Todts (Oxfam/Consortium 12-12) points out that journalists have evolved from specialists in the 1980s to all-rounders today. Therefore, they lack the necessary skills and background knowledge to report on international issues accurately. In line with Fenton (2010), our interviews show that, combined with the elevated workload in 
many newsrooms, journalists are more inclined to rely on INGO information subsidies. For example, Erik Todts (Oxfam/Consortium 12-12) points out that "iournalists miss the necessary background knowledge to cover international events. Moreover, the resources to produce news have been cut. As a consequence, I get ten phone calls from journalists every year with the request to explain the basics of an issue". Gerda Wylin (Caritas/Consortium 1212) further underlines that "the Internet has also changed a lot. There is so much information and everything needs to go fast. The pressure is higher, not only for journalists but also for us". The analysis shows that the higher work load for journalists translates differently in news access for MSF and Consortium 12-12, as will be discussed in the next section.

\section{Médecins Sans Frontières}

MSF press releases are remarkably more often published in the quality newspapers compared to press releases of the other organizations (see Table 2). The qualitative content analysis further points to relevant differences in the content of the press releases and news articles. Most press releases of the four organizations that resulted in news coverage discuss major crises, dramatic news events or were international events involving Belgians. This finding is in line with literature stating that "the media spotlight is apt to roam quickly from one disaster/emergency to another (...) and are drawn selectively to images of distress (...) Such fleeting coverage, at best, provides sparse context or historical background and even less follow-up coverage of post-conflict, post-emergency communities or longer-term processes of development" (Cottle and Nolan 2007:863). During the interview, Philippe Henon (Unicef/Consortium 12-12) confirmed that "some stories are too long-lasting, such as the Darfur crisis, and therefore almost never result in news coverage. We also observe several phases in the news cycle: the first days of an emergency are the most important ones and often result in news coverage, but the media attention decreases very quickly". Gerda Wylin (Caritas/Consortium 12-12) complained that "news production is an unpredictable process where some cases do and other cases don't result in media coverage. The news media are 
often too superficial and too much focused on scoops that deliver large audiences. There can be only one crisis, we never observe two crises in the news at the same time".

MSF is the only organization that succeeded in putting such ongoing crises and background information on the mainstream news agenda. The findings indicate that MSF is able to deploy its particular position as an expert and established news source on international aid issues to lever news attention to long-term disasters and underlying processes that generally fail to attract the attention of mainstream news media (Joye 2010). As other interviewees acknowledge, the decreasing attention of news media to foreign affairs generally and longterm humanitarian disasters in particular requires this agenda building capacity for international aid agencies. Indeed, MSF proactively and regularly distributes information subsidies about the settlement of international aid projects in different countries and regions. Moreover, MSF provides contextual information and reports about long-term disasters and distributes policy statements in reaction to political decisions (or their absence). Such policy statements often discuss global problems, including AIDS, the dismal situation of African refugees in Europe, or the international community's attitude to the civil war in Libya. The strategic choice to provide background knowledge and analysis was confirmed in the interview with Koen Baetens, who referred to MSF's "double mandate" as the organization not only strives for medical aid, but also wants to bear witness to the development of disasters or the persistence of injustice. Moreover, he stressed that MSF's PR efforts always depart from operations in the field to address the media as expert sources. Other interviews also show that this kind of in-depth reports on international events is especially appealing to quality newspapers. This conclusion is strengthened by the observation that MSF was also consulted in many other articles in the quality newspapers that were not directly inspired by press releases. Although these articles are not part of our sample they nonetheless illustrate that the quality newspapers actively consult MSF in the news gathering process.

The input-output analysis shows that many MSF press releases discussing ongoing crises and background information resulted in news coverage, such as a press release about the 
dismal situation of immigrants on the Italian island Lampedusa. Another example was an article in De Morgen (December 14) about the enduring crisis in the Central African Republic that verbatim summarizes an in-depth MSF report. During the interview, Koen Baetens also pointed towards MSF's long-standing relationship with photographers to visualize testimonies of people on the ground as a strategy to put "silent emergencies" on the agenda. We found evidence of this strategy's effectiveness in De Standaard's feature (November 17) of a MSF photo report about "urban survivors", people in conditions of extreme deprivation.

\section{Belgian Consortium for Relief Help}

In 2011, Consortium 12-12 distributed four retrospective press releases about the Haiti earthquake in 2010 and 23 press releases about the severe drought in the Horn of Africa. Our analysis indicates that the strategy to communicate only during limited periods about major events triggers relatively more news coverage than the constant and thus more often neglected flow of press releases coming from other organizations. Nonetheless, the analysis suggests that MSF anticipates Consortium 12-12's activities. MSF distributed only six press releases about the drought in the Horn of Africa and thus seems to avoid a battle for media attention with Consortium 12-12. Instead, MSF preferred to focus on international problems that are not covered by an intensive media campaign. The analysis supports this, as only one article contains PR material from both Consortium 12-12 and MSF. This article in De Morgen (July 29) focused on Consortium 12-12's call for fundraising and only refers to other organizations (MSF, Red Cross) in the final paragraph, which underwrites Consortium 1212 's privileged news access compared to other INGOs.

Philippe Henon (Unicef/Consortium 12-12) affirmed that Consortium 12-12's emphasis on spectacular international news events and wide-scale fundraising explains its higher presence in popular newspapers: "Belgian news media, and especially VTM (commercial broadcaster), intend to give the audience what it wants, and preferably news that can be linked to the Belgian context”. Previous studies have indeed shown that popular newspapers prefer dramatic news events, particularly when these can be domesticated for a Belgian 
audience (Joye 2010; Wouters, De Swert and Walgrave 2009). The latter was also the case for MSF, as two of the five articles in the popular newspapers that are based on MSF press releases discuss the dramatic and violent death of a Belgian MSF worker in Somalia and do not focus on MSF's international aid projects. Correspondingly, Cottle and Nolan (2007:870) also acknowledged this emerging tendency of the media to "routinely request and receive 'regionalized' material for their media reports".

In sum, the data show a different journalistic role for MSF and Consortium 12-12. Most Consortium 12-12 press releases have the purpose of raising short-term public awareness and donations for international crises (mobilization). In contrast, MSF established itself as an expert news source organization by regularly providing background information and reliable eyewitness accounts to journalists (Davis 2010; Powers 2012).

\section{European Commission and Belgian Ministry of Foreign Affairs}

The two government institutions are far less successful than the two INGOs in building the news agenda by means of information subsidies. Press releases are particularly focused on their financial contribution to international aid, which seems to appeal less to journalists than INGO expertise (MSF) or fundraising campaigns (Consortium 12-12).

This conclusion is especially applicable to the European Commission with only $15.1 \%$ of its press releases resulting in news coverage. Only three out of 73 articles are explicitly inspired by its press releases. In eight other news articles, we only found traces of European Commission press releases that were used as additional pieces of information for the broader scope of the news articles. Four of these articles discuss the civil war in Libya and the Ivory Coast and consist primarily of a description of the most recent settlements of the war and the activities or statements of the international community (European Union, United Nations, individual nation-states, etc.). The remaining four articles deal with the famines in North-Korea and the Horn of Africa, focusing on the local circumstances and international fundraising activities (two articles also contain Consortium 12-12 PR material). 
Contrary to the press releases of the European Commission and echoing the tendency to domesticate foreign news events, the Belgian Ministry of Foreign Affairs is slightly more successful in building the agenda with 12 news articles (success rate $32.4 \%$ ). Nonetheless, most of the articles are short, factual pieces that summarize the Foreign Affairs press release. One press release is covered in all four newspapers and announces a possible mission of the Belgian intervention team B-Fast at the scene of a nuclear disaster in Japan (March 12). The information in the press release is elaborated by the journalists in a limited way by adding contextual information about the functioning of the team or about interventions by other governments. Six articles elucidate the financial contribution of the Belgian Ministry of Foreign Affairs to fight the famine in the Horn of Africa. The remaining two articles published in two different newspapers on the same day - cover the death of a Belgian MSF worker in Somalia and are mainly based on the corresponding MSF press release that is supplemented with reactions of family members and friends gathered by the journalists. The Ministry of Foreign Affairs is only mentioned in the final paragraph as the responsible agency for the repatriation of the body.

Next to the issue of domestication, the inefficacy of European Commission press releases to be picked up by Belgian journalists might be explained by the fact that most of their press releases on international aid are distributed in English. These information subsidies cannot just be copy-pasted but instead require an extra effort from the Belgian journalist as they first need to be translated before they can be published. Therefore, efficiency considerations (Gans 1979) might also explain why European Commission press releases are less effective in building the news agenda compared to press releases of the Belgian Ministry of Foreign Affairs despite a substantially higher press release output.

\section{RQ2: Levels of agenda building}

Most articles (37 out of 56 articles or $66.1 \%$ ) in the sample are entirely written by the journalist in his/her own words, while thirteen articles are partly a verbatim reproduction of a 
press release and six articles are entirely copy-pasted from a press release. However, we need to acknowledge that agenda building also includes less explicit forms of recycling or copy-pasting. For example, the message of a press release can be paraphrased by a journalist with no supplementary information added to the actual content of the press release. Therefore, we did not restrict the analysis to the proportion of the article that is directly copypasted from the press release. We have included an analysis of the types of information that have been added to the press release by the journalist. This observation tempers the original optimism slightly, as we found that in fourteen of the 56 articles (25.0\%), the journalist did not supplement the information in the press release with additional news gathering, but merely copy-pasted or paraphrased the press release. In a considerable three quarters of the articles - about equally divided between the four organizations - journalists did supplement the information in the press release with additional news input, mainly extra facts, background information, in-depth analysis and reactions. This finding points towards a limited agenda building capacity of all four organizations in terms of "what to think".

In some cases, the press release appears to have initiated the news article; this especially seemed to be the case when the information in the press release was not supplemented with additional information. In contrast, in many other cases where the journalist actively produced a news report, the press releases seem to feature as nothing more than an additional source. One example is a news article about the civil war in Libya on October 5 by De Standaard correspondent Jorn De Cock, who is known as an expert in Middle-East coverage with a broad network of informants. In the news report, he piles together different pieces of background information about the regime of Muammar Kadhafi to understand the harshness of the dictator in the battle over Sirte. He adds depth to the article by quoting a civilian that was interviewed by Reuters, rounding out the article with a critical reflection on the humanitarian situation in the city. This is where he copies a quote from the MSF press release, complementing it with reactions from the International Red Cross and the Libyan political opposition. In other words, it seems that MSF's agenda building power in this specific case was quite limited. 
In other cases, the press release served as a source of inspiration to write a news piece about the topic while the journalist complemented the press releases by actively contacting the source organization with a request for additional or more current information, thereby also creating agenda building opportunities. A good example is an article in De Standaard on December 26 about the situation of Sudanese refugees. Clearly inspired by an MSF press release, the journalist opted to disregard a mere copy-pasting of the information subsidy and instead contacted the doctor who is quoted in the press release for current information. The article was further complemented with background information about the political situation in Sudan and an expert analysis.

The interviews further confirm that INGO PR activities are no longer limited to press releases or press conferences, but have extended to many additional strategies and tactics, such as the use of celebrities as INGO ambassadors. All interviewees acknowledged the importance of diversified news making practices in the contemporary news ecology. Koen Baetens for example referred to MSF's strategy of directing journalists to the weblogs of their employees in the field, or offering personal talks with Belgian MSF workers about their experiences. Philippe Henon (Unicef/Consortium 12-12) stated that "formerly, when we used to organize a press conference, many journalists would have shown up. Today we really need to have something extraordinary to say or nobody shows up. So we adjusted our strategy by including informal media contacts and giving the journalists more exclusive information".

In accordance with similar research by Van Leuven, Deprez and Raeymaeckers (2013), we found that 46 of 56 articles $(82.1 \%)$ do not refer to the press releases as a source of information. It seems that journalists prefer to veil PR material in a "smokescreen of anonymity" (Reich 2010) to safeguard their professional image of editorial independence, thereby presenting the PR information as original journalistic work instead of a form of free advertising in favor of specific private interests. Often, quotes from press releases are presented as if the journalist contacted the organization. Six articles vaguely refer to the selected organizations as an "information source" (e.g., "report", "spokesperson"), but only 
four articles (7.1\%) explicitly state that the journalist used press release material (e.g., "The Foreign Secretary declared in a press release..."). Three of these four articles refer to the national news agency Belga in their byline. Seven other articles that have Belga in their byline do not explicitly mention the use of press releases, which points to a ladder of news sourcing.

\section{Discussion and conclusion}

Applying a combination of an input-output analysis and in-depth interviews with INGO communication professionals, this article examined the assumption that the incorporation of press releases in editorial content could be an avenue for INGOs to gain wider news access. In line with the work of Cottle and Nolan (2007) our study shows that the two selected INGOs invest considerable time and resources in the production of "media packages" to gain news access. As a result, we found that Belgian newspapers in their reporting on international aid issues are more inclined to publish INGO press releases compared to press releases that are distributed by government institutions (RQ1). For both types of organizations, we found that their agenda building capacity is enhanced on the one hand, as in most cases their information subsidies are presented as original journalistic work. On the other hand, we need to tone down one-sided conclusions as - in contrast with the findings of Fenton (2010) - our data show that most press releases are not just copy-pasted, but they are instead combined with additional sources and information (RQ2). In sum, it seems that INGO press releases and to a lesser degree government institutions' press releases - are often consulted as a news source in international aid coverage, but their agenda building capacities in terms of "what to think" seem rather limited if we only take into consideration the amount of text that has been taken from press releases. Further research in the field of framing analysis is necessary to assess the extent to which this capacity is sufficient to determine the overall frame of these news articles. 
In terms of theoretical implications, the analysis provides additional insight into the changing constellation of news sources related to the global public sphere. It confirms that MSF and Consortium 1212 are key players in the global civil society to whom Belgian journalists turn for information about global issues, international aid in this case. Nonetheless, as Waisbord (2011:151) states, the field of NGOs is too diverse "in terms of issues and demands, approaches to news making, and perception of legitimacy as sources of information" to generalize the findings of this study. Indeed, with respect to the INGOs under consideration in this article, the content analysis identified important differences between the two types of INGOs studied here, a finding that was also supported by the interviews. In line with the findings of Cottle and Nolan (2007), our study shows that - in an increasingly competitive international aid field - both INGOs use different strategies to "brand" themselves and to communicate with journalists and audiences. MSF is most effective in setting the news agenda in absolute numbers, especially in the quality newspapers. Following Waisbord (2011), MSF can be considered as a "technical" INGO that distributes background reports about the settlement of international aid projects in different countries and regions throughout the year. From this authoritative position as an expert source on the ground, MSF is able to lever news attention to long-term disasters (Cottle 2009; Davis 2010; Powers 2012). The role of the Belgian Consortium for Relief Help 12-12 is different as its communication efforts are focused on sudden crises and fundraising. The efficacy of this mobilization strategy is confirmed by the finding that Consortium 12-12 is most effective in setting the news agenda in relative numbers. Consortium 12-12's emphasis on spectacular international news events, particularly when these can be domesticated for a Belgian audience, is especially appealing to popular newspapers.

Waisbord (2011) and Deacon (2003) also point out that we need to acknowledge the wide variety in NGOs' success in gaining news access. Most press releases in this study focused on international disasters that appeal to traditional news values (drama), while the chances of other issues and INGOs - especially when they interfere with state or corporate interests (see Gaber and Willson 2005) - to build the news agenda may be much more limited. 
Furthermore, the two INGOs under consideration in this study are relatively well-resourced organizations with strong media connections, while other NGOs may lack the social and material means to develop a broad range of media-tailored strategies (Deacon 2003; Fenton 2010). It might also be that Belgium - with its high concentration of NGOs - is a distinct case where journalists automatically pay more attention to NGO press releases. Further research on INGOs in different countries that cover different "global issues", such as global warming and human rights, is thus necessary to formulate an overall conclusion with regard to INGOs' news making efforts in the global public sphere. Additionally, it is also necessary to expand our focus from press releases in newspapers to other INGO communication strategies. This is especially important considering the changing ecology of news where INGOs may also be more inclined to skip established news organizations as intermediary channels to influence policy making and instead deploy new digital leverage to communicate directly with citizens, activists, or policy makers.

Another critical note is made by Davis (2010) who points out that because most INGOs focus on "single issues", their development as an overall important actor in the global public sphere is hindered. In other words, rather than powerful actors in the global public sphere who can impact a broad range of decision-making processes, INGOs are to be regarded more as effective and skilled newsmakers in certain specific fields of discourse, such as international aid. This might also be one of the reasons why both government institutions in this case study appear to be "less successful" than the INGOs in their news making efforts. Additionally, INGOs have stronger incentives to shape news coverage as it is their main instrument to influence policy making. By contrast, government institutions are less dependent on media coverage to reach their goals, since they already are the key decision makers. For them, news coverage is more a means to communicate decisions to citizens.

One final remark deals with our interview study. Although documenting a general outline of INGO practices, the in-depth interviews were conducted in 2009. Since then the political and economic foundations of the global public sphere have undergone major changes (cf. the enduring global economic and financial crisis). Further research is needed to investigate the 
extent to which INGOs have been hit by this crisis and to what extent they have adjusted their communication strategies.

Overall, the main contribution of our study is that it adjusts the image of PR as "a wizard-like character who hides behind the curtain, pulling the strings that advance elite interests, manipulating democratic processes and using ethically questionable tactics to influence the outcomes of public policy debate" (Greenberg, Knight and Westersund 2011:76). Those practices undoubtedly do exist, but our findings illustrate that the development towards a digital and global public sphere offers opportunities to non-established news sources - with little direct influence on the political stage - to gain news access and possibly change the outcome of the decision-making process. In this sense, despite the fact that the resources to produce information subsidies and set up media-tailored strategies are unequally distributed, we agree with Mclntosh White (2012) that the changing news ecology offers new possibilities for INGOs to raise their voice in the public debate. From this point of view, PR material can be a positive contribution to the global public sphere in that INGOs and governments intend to inform the public about matters of general interest.

\section{Funding}

This research received no specific grant from any funding agency in the public, commercial, or not-for-profit sectors.

\section{Notes}

${ }^{1}$ For more detailed information about the coding sheet of the input-output analysis and the topic list of the in-depth interviews, please contact the authors. 


\section{References}

Aday, Sean, and Steven Livingston. 2008. "Taking the State out of State-Media Relations Theory." Media, War \& Conflict 1 (1): 99-107.

Beck, Ullrich. 1992. Risk Society. Towards a new Modernity. London: Sage.

Boorstin, Daniel. [1962] 1992. The Image: A Guide to Pseudo-Events in America. New York: Vintage Books.

Buijs, Kees, Serena Daalmans, Annemarie Frye, Daphne ten Haaf, Ellen Hijmans, and Pytrik Schafraad. 2009. "De Onafhankelijkheid van Nieuwsbronnen en de Kwaliteit van de Journalistiek." Paper presented at the annual meeting for Etmaal van de Communicatiewetenschap, Gent, February.

Cammaerts, Bart, and Leo Van Audenhove. 2005. "Online Political Debate, Unbounded Citizenship, and the Problematic Nature of a Transnational Public Sphere." $\underline{\text { Political }}$ Communication $22(2):$ 179-196.

Castells, Manuel. 2008. "The New Public Sphere." Annals of the American Academy of Political and Social Science 616: 78-93.

Castells, Manuel. 2010. "Communication Power." In Media and Society, ed. James Curran, 3-17. London: Blommsurry Academic.

Chouliaraki, Lilie. 2013. The Ironic Spectator. Cambridge: Polity Press.

Cottle, Simon. 2000. "Rethinking News Access." Journalism Studies 1 (3): 427-448.

Cottle, Simon, and David Nolan. 2007. "Global Humanitarianism and the Changing AidMedia Field." Journalism Studies 8 (6): 862-878.

Cottle, Simon. 2009. Global Crisis Reporting. Berkshire: Open University Press.

Curran, James. 2010. "Communication and Globalization." In Rethinking Communication, ed. Stuart Allan, 8-10. Cresskill, NJ: Hampton Press.

Curtin, Patricia A. 1999. "Reevaluating Public Relations Information Subsidies." Journal of Public Relations Research 11 (1): 53-90. 
Davies, Nick. 2008. Flat Earth News. London: Vintage.

Davis, Aeron. 2000. "Public Relations, News Production and Changing Patterns of Source Access in the British National Media." Media, Culture and Society 22 (1): 39-59.

Davis, Aeron. 2010. "Media and Politics." In Media and Society, ed. James Curran, 83-102. London: Bloomsburry Academic.

Deacon, David. 1996. "The Voluntary Sector in a Changing Communication Environment." European Journal of Communication 11 (2): 173-199.

Deacon, David. 2003. "Non-Governmental Organisations and the Media." In News, Public Relations and Power, ed. Simon Cottle, 99-115. London: Sage.

De Bens, Els, and Karin Raeymaeckers. 2010. De Pers in België. Leuven: LannooCampus. Fenton, Nathalie. 2010. "NGOs, New Media and the Mainstream News: News from Everywhere." In New Media, Old News, ed. Nathalie Fenton, 153-168. London: Sage.

Franklin, Bob. 2011. "Sources, Credibility and the Continuing Crisis of UK Journalism." In Journalists, Sources and Credibility, ed. Bob Franklin and Matt Carlson, 90-106. London: Routledge.

Gaber, Ivor, and Alice Wynne Willson. 2005. "Dying for Diamonds: The Mainstream Media and the NGOs - A Case Study of ActionAid." In Global Activism, Global Media, ed. Wilma de Jong, Martin Shaw and Neil Stammers, 95-109. London: Pluto Press. Gandy, Oscar H. 1982. Beyond Agenda Setting. Norwood: Ablex.

Gans, Herbert J. 1979. Deciding What's News. London: Constable.

Greenberg, Josh, Graham Knight, and Elizabeth Westersund. 2011. "Spinning Climate Change." The International Communication Gazette 73 (1-2): 65-82.

Habermas, Jürgen. 1974. "The Public Sphere: An Encyclopedia Article (1964).” New German Critique 3 (Autumn): 49-55.

Habermas, Jürgen. 1992. "Further Reflections on the Public Sphere." In Habermas and the Public Sphere, ed. Craig Calhoun, 421-461. Cambridge: MIT Press. 
Hall, Stuart, Chas Critcher, Tony Jefferson, John Clarke, and Brian Roberts. [1978] 1999. "Policing the Crisis." In News: A Reader, ed. Howard Tumber, 249-256. Oxford: Oxford University Press.

Joye, Stijn. 2010. De Media(de)constructie van Rampen. PhD Thesis, Ghent University: Belgium.

Kennedy, Denis. 2009. "Selling the Distant Other." The Journal of Humanitarian Assistance 411.

Lams, Lutgard. 2011. "Newspapers' Narratives Based on Wire Stories: Facsimiles of Input?" Journal of Pragmatics 43: 1853-1864.

Lee, Chin-Chuan, Joseph M. Chan, Zhongdang Pan, and Clement Y.K. So. 2005 "National Prisms of a Global 'Media Event." In Mass Media and Society, ed. James Curran and Michael Gurevitch, 320-335. London: Hodder Arnold.

Lewis, Justin, Andrew Williams, Bob Franklin, James Thomas, and Nick Mosdell. 2006. The Quality and Independence of British Journalism. Cardiff: Cardiff University.

Livingston, Steven, and W. Lance Bennett. 2003. "Gatekeeping, Indexing, and Live-Event News: Is Technology Altering the Construction of News?" Political Communication 20 (4): 363-380.

Livingston, Steven and Gregory Asmolov. 2010. "Networks and the Future of Foreign Affairs Reporting." Journalism Studies 11 (5): 745-760.

Manheim, Jarol B. 1998. "The News Shapers: Strategic Communication as a Third Force in News Making." In The Politics of News: The News of Politics, ed. Doris Graber, Denis McQuail and Pippa Norris, 94-109. Washington (D.C.): Congressional Quarterly.

McIntosh White, Judith. 2012. "The Communicative Action of Journalists and Public Information Officers: Habermas Revisited.” Journalism Practice 6 (4): 563-580.

McManus, John H. 2009. "The Commercialization of News." In The Handbook of Journalism

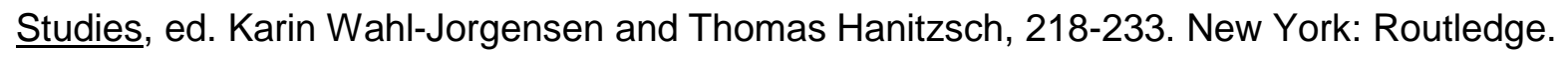
Miller, David. 1993. "Official Sources and 'Primary Definition'." Media, Culture and Society 15 (3): 385-406. 
Mooijman, Ruben. 2005. Weinig Verantwoording Besteding Hulpgeld.

http://www.doordacht.be/nieuws/pdf/weinig_verantwoording_besteding_hulpgeld.pdf.

Orgad, Shani and Corinne Vella. 2012. Who Cares? Challenges and Opportunities in Communicating Distant Suffering: A View from the Development and Humanitarian Sector. London: POLIS.

Paterson, Chris. 2006. News Agency Dominance in International News on the Internet. http://ics-www.leeds.ac.uk/papers/cicr/exhibits/42/cicrpaterson.pdf.

Powers, Matthew. 2012. "Ecologies of Information Production." Paper presented at the annual meeting for the ICA, Phoenix, May.

Quandt, Thorsten. 2008. “(No) News on the World Wide Web?" Journalism Studies 9 (5): 717-738.

Reich, Zvi. 2010. "Measuring the Impact of PR on Published News in Increasingly Fragmented News Environments." Journalism Studies 11 (6): 799-816.

Reich, Zvi. 2011. "Source Credibility as a Journalistic Work Tool." In Journalists, Sources and Credibility, ed. Bob Franklin, and Matt Carlson, 19-36. London: Routledge.

Sallot, Lynne M., and Elizabeth A. Johnson. 2006. "Investigating Relationships Between Journalists and Public Relations Practitioners." Public Relations Review 32 (2): 151-159.

Sambrook, Richard. 2010. Are Foreign Correspondents Redundant? Oxford: Reuters Institute for the Study of Journalism.

Seu, Irene B. 2011. "Shoot the Messenger': Dynamics of Positioning and Denial in Response to Human Rights Appeals." Journal of Human Rights Practice 3 (2): 139-161.

Sigal, Leon V. [1973] 1999. "Reporters and Officials: The Organization and Politics of Newsmaking (Excerpt). In News: A Reader, ed. Howard Tumber, 224-234. Oxford: Oxford University Press.

Thrall, Trevor A., Jaime Lollio-Fakhreddine, Jon Berent, Lana Donnelly, Wes Herrin, Zachary Paquette, Rebecca Wenglinski, and Amy Wyatt. 2008. "Star Power." The International Journal of Press/Politics 13 (4): 362-385. 
Van Hout, Tom, and Geert Jacobs. 2008. "News Production Theory and Practice." Pragmatics 18 (1): 59-85.

Van Leuven, Sarah, Annelore Deprez, and Karin Raeymaeckers 2013. "Increased News Access for International NGOs? How MSF Press Releases Built the Agenda of Flemish Newspapers (1995-2010)." Journalism Practice 7 (4): 430-445.

Vargas, Lucila, and Lisa Paulin. 2007. "Rethinking 'Foreign News' from a Transnational Perspective. In From Pigeons to News Portals, ed. David D. Perlmutter and John Maxwell Hamilton, 20-46. Baton Rouge: Louisiana State University Press.

Volkmer, Ingrid. 2003. "The Global Network Society and the Global Public Sphere." Development 46 (1): 9-16.

Volkmer, Ingrid, and Amira Fridaus. 2013. "Between Networks and 'Hierarchies of Credibility"'. In Rethinking Journalism, ed. Chris Peters and Marcel Broersma, 101-113. London: Routledge.

Waisbord, Silvio. 2011. "Can NGOs Change the News?" International Journal of Communication 5: 142-165.

Webster, Frank. 2011. "Information and Democracy: The Weakening of Social Democracy." In Media Perspectives for the 21st Century, ed. Stylianos Papathanassopoulos, 21-40. London: Routledge.

Wolfsfeld, Gadi. 2011. Making Sense of Media and Politics. London: Routledge.

Wouters, Ruud, Knut De Swert, and Stefaan Walgrave. 2009. Een Venster op de Wereld. Brussel: Vlaams Vredesinstituut. 